\title{
Influence of temperature and culture media on growth and lipolytic activity of deep-sea Halomonas sulfidaeris LAMA 838 and Marinobacter excellens LAMA 842
}

\author{
Gabriela Scholante Delabary'1, Maria Carolina da Silva' ${ }^{1}$, Cibele Silveira da Silva', Letícia Zanatta \\ Baratieri', Thiago Meinicke de Melo', Cesar Augusto Stramosk', André Oliveira de Souza Lima', \\ Marcus Adonai Castro da Silva ${ }^{1, *}$ (1) \\ 1 Universidade do Vale do Itajaí, Escola do Mar, Ciência e Tecnologia \\ (R. Uruguai, 458 - Centro, Itajaí - SC, 88302-901)
}

*Corresponding author: marcus.silva@univali.br

\section{Abstract}

Bacteria with lipolytic activity are widespread in the marine environment. These organisms can be used as a source of lipases with activity in unusual conditions such as low temperatures and high salinities. These characteristics allow them to be applied to several industrial processes and products including wastewater treatment and detergent production. In this context the lipolytic activity of bacteria isolated from deep-sea sediments of the South Atlantic was evaluated. Among the collection studied, two strains, Halomonas sulfidaeris LAMA 838 and Marinobacter excellens LAMA 842, were selected for further analysis concerning their growth and lipolytic activity in different temperatures and culture media. Both strains were characterized as mesophiles: $H$. sulfidaeris LAMA 838 grew best at $30^{\circ} \mathrm{C}$, while $M$. excellens LAMA 842 showed a maximum growth rate between 20 and $25^{\circ} \mathrm{C}$. Maximum lipolytic activity for both microorganisms was observed above $45^{\circ} \mathrm{C}$, but only M. excellens LAMA 842 had lipolytic activity at low temperatures $\left(5^{\circ} \mathrm{C}\right)$ as well. Considering the culture media employed, $H$. sulfidaeris LAMA 838 grew better in marine broth without Tween 40, while $M$. excellens LAMA 842 grew best in marine broth supplemented with Tween 40. Both organisms had maximum lipolytic activity in rich or minimal media supplemented with Tween 40 . These results demonstrate the potential of deep-sea bacteria as sources of lipases and indicate conditions that may be used in their cultivation and for the production of industrially relevant enzymes.

Descriptors: deep-sea bacteria, microbial growth, lipolytic activity, psychrotolerants.

\section{INTRODUCTION}

Lipases are enzymes capable of catalyzing the hydrolysis of long-chain triglycerides to free fatty acids (Treichel et al., 2010), as well as synthesizing esters from glycerol (Lailaja and Chandrasekaran, 2013). These enzymes are used in the food and paper industries, as supplements to detergents, synthesis of biopolymers, production of biodiesel, purification of pharmacologically relevant chemical compounds, cosmetics, agrochemicals,

Submitted on: 29/August/2019

Approved on: 11/January/2020

Editor: Rubens M. Lopes

Associate Editor: Camila N. Signori

() 2019 The authors. This is an open access article distributed under the terms of the Creative Commons license. bioremediation, and in wastewater treatment (LópezLópez et al., 2014).

Lipases from deep-sea bacteria may have peculiar characteristics, such as tolerance to high pressures and low temperatures. They are also easy to adapt to large scale cultivation and are active in a wide range of $\mathrm{pH}$ values and temperatures. These features confer high stability and a high specificity for their substrates, and can be attributed to the oligotrophic environments and low temperatures to which these organisms are imposed, as well as the molecules involved in their complex metabolisms. They have great potential in research seeking new products of industrial interest (Dalmaso et al., 2015; Hu et al., 2015). In this context, different marine microorganisms have already been described as extracellular enzyme producers (Odisi et al., 2012). 
Lipase production by deep-sea bacteria may be influenced by environmental factors such as glucose and yeast extract concentration, as reported for Thalassospira permensis (Kai and Peisheng, 2016). The types of lipids present in the medium may also influence the activity of lipases, as reported for the strain Psychrobacter sp. C18 (Chen et al., 2011). All these influences may be interpreted as mechanisms to increase the survival of bacteria in deepsea environments when organic matter containing lipids becomes available for growth. Nevertheless, variations may occur according to the needs or tolerances of the microorganisms, and these variations may influence the enzymatic activity (Kiran et al., 2014).

The genera Marinobacter (Gorshkova et al., 2003) and Halomonas (Kaye and Baross, 2004) belong to the class Gammaproteobacteria and are commonly found in different marine ecosystems; they may present different optimum temperatures for growth, being psychrophiles, mesophiles or thermophiles, and they show great tolerance to salinity and $\mathrm{pH}$ (Silva et al., 2013; Ng et al., 2014; Zhang et al., 2016). The ability to occupy various physical and chemical environments indicates great versatility and phenotypic diversity in these genera, so some species of Halomonas and Marinobacter have already been described to produce lipases (Kumar et al., 2012). The strains of Halomonas and Marinobacter studied by these authors produced lipases with optimum temperature between 50 and $65^{\circ} \mathrm{C}$, and optimum $\mathrm{pH}$ between 9.0 and 9.5. The lipases of the Marinobacter evaluated were also stable at $60^{\circ} \mathrm{C}$ for one hour. Thermal stability for the Halomonas strain was not assessed. Oves et al. (2017) reported the thermal $\left(70^{\circ} \mathrm{C}\right)$ and $\mathrm{pH}(6-8)$ stability of the lipolytic activity of Marinobacter lipolyticus strain CEES 33 isolated from the Red Sea. Finally, the lipase of Marinobacter litoralis strain SW- 45 was active and stable between $\mathrm{pH}$ values of 7.0 and 9.5 , and temperatures of 30 and $50^{\circ} \mathrm{C}$, with maximum activity at $\mathrm{pH} 8.0$ and $50^{\circ} \mathrm{C}$ (Musa et al., 2018).

The study of lipases of these deep-sea bacteria is important in several ways. Firstly, it provides us with a better understanding of the mechanisms of microbial survival at these harsh environments. Secondly, the success of the biotechnological applications of these enzymes requires that we know the conditions under which they are able to function. Lastly, the basic knowledge about lipases and their producing organisms is essential to enable an eventual commercial production of these molecules. In this context, the objective of this work was to evaluate the influence of the Tween substrate and temperature on the growth of Halomonas sulfidaeris LAMA 838 and Marinobacter excellens LAMA 842 bacteria and the activity of their synthesized extracellular lipases. This objective was stimulated by the fact that few studies have identified these bacterial species as lipases producers (Silva et al., 2013).

\section{MATERIAL AND METHODS}

\section{SOURCE OF STRAINS}

The bacteria used in this work were isolated and identified by Silva et al. (2013) from sediment samples of two different regions of the South Atlantic Ocean: the Walvis Ridge Sector - WRS $\left(20^{\circ}-33^{\circ} \mathrm{S}, 5^{\circ} \mathrm{W}, 10^{\circ} \mathrm{E}\right)$ and the South Equatorial MAR Sector - SEMS $\left(2^{\circ} \mathrm{N}-10^{\circ} \mathrm{S}, 12^{\circ}-22^{\circ} \mathrm{W}\right)$ (Perez et al., 2012). Further details of the strains used are given in Table 1. The bacteria were evaluated for lipolytic potential and through a selection for best performance on imposed substrates and culture conditions.

\section{SCREENING FOR LIPOLYTIC ACTIVITY}

The collection of strains was screened for lipolytic activity on 55.25g/l Zobell Marine Agar 2216 plates (Himedia Laboratories, Mumbai, India) supplemented with $0.5 \%$ Tween 20 (T20), Tween 40 (T40), Tween 60 (T60) or Tween 80 (T80). The plates were pointinoculated in triplicate and incubated at three different temperatures, $5^{\circ} \mathrm{C}$ (fourteen days of incubation), $15^{\circ}$ (also fourteen days of incubation), and $30^{\circ} \mathrm{C}$ (incubated for seven days). After incubation, substrate hydrolysis was visualized as the precipitation of crystals around the colonies (Smibert and Krieg, 1994). This activity was quantified by an enzymatic index (El) obtained from the diameters of the colonies $(C)$ and their respective hydrolysis zones $(\mathrm{H})$ according to the formula: $\mathrm{El}=\mathrm{H} / \mathrm{C}$ (Hankin and Agnostakis, 1975).

\section{LIPASE ASSAY}

For the lipase assay, crude enzymatic extracts were prepared by culturing the microorganisms in Erlenmeyer flasks containing $75 \mathrm{ml}$ of $40.25 \mathrm{~g} / \mathrm{l}$ Zobell Marine Broth 2216 (MB, Himedia Laboratories, Mumbai, India) supplemented with $0.5 \% \mathrm{~T} 20$ and $75 \mu$ l of bacterial inoculums. The culture flasks were incubated at $30^{\circ} \mathrm{C}$ for $48 \mathrm{~h}$. After incubation, $1 \mathrm{ml}$ aliquots were collected 
from the culture flasks and centrifuged at 8,116.6 $\mathrm{xg}$ for 10 mins. The supernatant was considered the crude enzymatic extract.

Spectrophotometric assays of lipolytic activity were conducted as described by Pinsirodom and Parkin (2001). Briefly, $1.0 \mathrm{ml}$ of crude enzymatic extracts were added to $2.5 \mathrm{ml}$ of a Tris $\mathrm{HCl}$ buffer solution $(\mathrm{pH}=8.2)$ and $2.5 \mathrm{ml}$ of the substrate p-nitrophenyl palmitate (pNPP). As controls, we used crude enzymatic extracts that were inactivated by boiling $\left(100^{\circ} \mathrm{C}\right)$ for $10 \mathrm{mins}$ on a thermoblock. A blank was also prepared using distilled water in place of the crude enzymatic extract. The assay mixtures were incubated at different temperatures depending on the experiment (described below) for one

Table 1. Bacterial strains used in the present study, their isolation medium and identification (Silva et al., 2013). MA, Marine Agar; MBC, Marine Agar supplemented with carboxymethylcellulose (1\%); MAT40, Marine Agar supplemented with Tween40 (1\%).

\begin{tabular}{|c|c|c|c|c|c|}
\hline Strain & Isolation medium & Identification & Strain & $\begin{array}{l}\text { Isolation } \\
\text { medium }\end{array}$ & Identification \\
\hline LAMA 616 & MA & Staphylococcus sp. & LAMA 720 & MA & Bacillus thuringiensis \\
\hline LAMA 617 & MA & Idiomarina sp. & LAMA 723 & MA & Psychrobacter sp. \\
\hline LAMA 618 & MA & Oceanobacillus iheyensis & LAMA 732 & MA & Bacillus infantis \\
\hline LAMA 619 & MA & Terribacillus saccharophilus & LAMA 734 & MA & Halomonas boliviensis \\
\hline LAMA 622 & MBC & Cobetia marina & LAMA 739 & MA & Brevibacillus parabrevis \\
\hline LAMA 624 & MBC & Psychrobacter sp. & LAMA 751 & MA & Oceanobacillus iheyensis \\
\hline LAMA 625 & MBC & Cobetia marina & LAMA 754 & MA & Nesterenkonia sp. \\
\hline LAMA 627 & MBC & Halomonas boliviensis & LAMA 757 & MA & Nesterenkonia sp. \\
\hline LAMA 632 & MBC & Halomonas sulfidaeris & LAMA 762 & MA & Bacillus sp. \\
\hline LAMA 633 & MBC & Halomonas sulfidaeris & LAMA 767 & MA & Paenibacillus glucanolyticus \\
\hline LAMA 634 & MBC & Halomonas sp. & LAMA 780 & MA & $\begin{array}{l}\text { Staphylococcus saprophyticus } \\
\text { subsp. bovis }\end{array}$ \\
\hline LAMA 636 & MBC & Halomonas sulfidaeris & LAMA 781 & MA & Bacillus sp. \\
\hline LAMA 637 & MBC & Planomicrobium okeanokoites & LAMA 782 & MA & non identified \\
\hline LAMA 638 & MBC & Halomonas sp. & LAMA 784 & MA & Pseudoalteromonas issachenkonii \\
\hline LAMA 639 & MBC & Psychrobacter nivimaris & LAMA 786 & MA & Halomonas sulfidaeris \\
\hline LAMA 641 & MBC & Psychrobacter nivimaris & LAMA 791 & MAT40 & Halomonas sp. \\
\hline LAMA 642 & MBC & Halomonas sp. & LAMA 794 & MAT40 & Halomonas boliviensis \\
\hline LAMA 643 & MBC & Halomonas boliviensis & LAMA 796 & MAT40 & Halomonas sp. \\
\hline LAMA 644 & MBC & Halomonas boliviensis & LAMA 797 & MAT40 & Halomonas boliviensis \\
\hline LAMA 645 & MBC & Halomonas sp. & LAMA 799 & MAT40 & Psychrobacter nivimaris \\
\hline LAMA 646 & MBC & Halomonas boliviensis & LAMA 802 & MAT40 & Halomonas boliviensis \\
\hline LAMA 670 & MA & non identified & LAMA 807 & MAT40 & Halomonas boliviensis \\
\hline LAMA 682 & MA & non identified & LAMA 809 & MAT40 & Halomonas sp. \\
\hline LAMA 683 & MA & Idiomarina sp. & LAMA 810 & MAT40 & Halomonas boliviensis \\
\hline LAMA 687 & MA & Bacillus pocheonensis & LAMA 817 & MAT40 & $\begin{array}{c}\text { Staphylococcus cohnii subsp. } \\
\text { urealyticus }\end{array}$ \\
\hline LAMA 690 & MA & Bacillus sp. & LAMA 818 & MAT40 & Psychrobacter nivimaris \\
\hline LAMA 691 & MA & Idiomarina loihiensis & LAMA 820 & MAT40 & $\begin{array}{c}\text { Staphylococcus cohnii subsp. } \\
\text { urealyticus }\end{array}$ \\
\hline LAMA 692 & MA & Bacillus sp. & LAMA 822 & MAT40 & $\begin{array}{c}\text { Staphylococcus cohnii subsp. } \\
\text { urealyticus }\end{array}$ \\
\hline LAMA 694 & MA & Terribacillus saccharophilus & LAMA 833 & MAT40 & Staphylococcus xylosus \\
\hline LAMA 695 & MA & Sporosarcina saromensis & LAMA 837 & MAT40 & Halomonas sp. \\
\hline LAMA 701 & MA & Brevibacterium iodinum & LAMA 838 & MAT40 & Halomonas sulfidaeris \\
\hline LAMA 702 & MA & Micrococcus luteus & LAMA 842 & MAT40 & Marinobacter excellens \\
\hline LAMA 704 & MA & Halomonas sp. & LAMA 878 & MA & Bacillus pocheonensis \\
\hline LAMA 706 & MA & Oceanobacillus sp. & LAMA 879 & MA & Halomonas sp. \\
\hline LAMA 713 & MA & Bacillus sp. & LAMA 892 & MA & Bacillus sp. \\
\hline
\end{tabular}


hour. After the incubation period, the absorbance at the wavelength of $410 \mathrm{~nm}$ was measured against the blank. The absorbance values obtained were then converted to concentration units using a calibration curve based on p-nitrophenol as standard (Table 2).

\section{INFLUENCE OF TEMPERATURE ON GROWTH AND LIPASE ACTIVITY}

To estimate the optimum, maximum and minimum temperatures for growth, Erlenmeyer flasks of $125 \mathrm{ml}$ capacity containing $75 \mathrm{ml}$ of MB supplemented with $1.0 \%$ T20 were inoculated with $75 \mu$ l of bacteria, in triplicate, from a culture prepared in Marine Broth $\left(30^{\circ} \mathrm{C}\right.$, incubated for 24 hours). T20 was chosen for this analysis because of its lower complexity molecular structure, which facilities its use by the microorganisms for their growth. The inoculated flasks were incubated at $5,10,15,20,25$ and $30^{\circ} \mathrm{C}$ under an agitation at $2,012 \mathrm{xg}$ for different periods of time, depending on the incubation temperature. For 25 and $30^{\circ} \mathrm{C}$, the incubation time was $24 \mathrm{~h}$; for 15 and $20^{\circ} \mathrm{C}, 48 \mathrm{~h}$; and for 5 and $10^{\circ} \mathrm{C}, 120 \mathrm{~h}$. Using the calibration curve (Table 2), the optimal growth was determined from the highest growth rate by converting the absorbance at $600 \mathrm{~nm}$ to cells per milliliter (Breznak and Costilow, 1994). To investigate the influence of temperature on enzymatic activity, the crude enzymatic extracts were incubated for one hour at the following temperatures: 5, 10, 15, 20, 25, $30,35,40,45$ and $50^{\circ} \mathrm{C}$. Otherwise, the lipase assays were conducted as described above.

\section{INFLUENCE OF CULTURE MEDIA ON GROWTH AND LIPASE ACTIVITY}

Growth of selected bacteria was also evaluated in two complex media, $\mathrm{MB}$ and $\mathrm{MB}$ supplemented with $0.5 \% \mathrm{~T} 40(\mathrm{MB}+\mathrm{T} 40)$, and a minimal medium supplemented with $0.5 \%$ T40 (MM+T40). Composition of the minimal medium $(1,000 \mathrm{ml})$ was as follows: Tris $\mathrm{HCl}(\mathrm{pH} 7.5), 7.88 \mathrm{ml} ; \mathrm{NH}_{4} \mathrm{Cl}, 10.16 \mathrm{~g} ; \mathrm{K}_{2} \mathrm{HPO}_{4}, 0.075 \mathrm{~g}$;
$\mathrm{FeSO}_{4} * 7 \mathrm{H}_{2} \mathrm{O}, 0.028 \mathrm{~g}$; solution of vitamins (for $200 \mathrm{ml}$ : pyridoxine, 0.02g; thiamine, $0.01 \mathrm{~g}$; riboflavin, $0.01 \mathrm{~g}$; calcium pentanoate, $0.01 \mathrm{~g}$; nicotinic acid, $0.01 \mathrm{~g}$; vitamin B12, 0.01g; biotin, 0.004g; folic acid, 0.004g), $1.00 \mathrm{ml}$; artificial sea water (for $1,000 \mathrm{ml}: \mathrm{NaCl}, 23.38 \mathrm{~g}$; $\mathrm{MgSO}_{4}{ }^{*} 7 \mathrm{H}_{2} \mathrm{O}, 24.65 \mathrm{~g} ; \mathrm{KCl}, 1.49 \mathrm{~g} ; \mathrm{CaCl}^{*} 2 \mathrm{H}_{2} \mathrm{O}, 2.94 \mathrm{~g}$ ), $500 \mathrm{ml}$; distilled water, $500 \mathrm{ml}$. In this experiment, T40 was chosen because its carbon chain is palmitate, and this reagent was also used in the culture media in the enzyme assay.

From precultures prepared in the three different media ( $30^{\circ} \mathrm{C}$, incubated for 24 hours), Erlenmeyer flasks of $125 \mathrm{ml}$ capacity containing $75 \mathrm{ml}$ of the three different media were inoculated with $75 \mu \mathrm{l}$ of the precultures prepared in the same media for preadaptation. The inoculated flasks were incubated at $30^{\circ} \mathrm{C}$ for $48 \mathrm{~h}$ (MB and $\mathrm{MB}+\mathrm{T} 40)$ or $120 \mathrm{~h}(\mathrm{MM}+\mathrm{T} 40)$. Periodically the optical density at $600 \mathrm{~nm}$ was measured and later used for the calculation of generation times of the organisms in the different culture media (White et al., 2012). The lipolytic activity was also assayed in the different media by incubating the crude enzymatic extracts for one hour at $30^{\circ} \mathrm{C}$ as described above. The lipolytic activity results (calculated using the calibration curve as previously described) were divided by the number of colony forming units (CFUs) for each of the evaluated bacteria.

\section{DATA ANALYSIS}

The growth rates of each microorganism were compared at the different temperatures and culture media using one-way analysis of variance (ANOVA). Four analyses were conducted separately: growth temperature for LAMA 838, growth temperature for LAMA 842, culture media for LAMA 838, and culture media for LAMA 842. In all cases confidence limits of $95 \%$ and degrees of significance of 0.05 were considered. If significant variability was detected, a Tuckey's test was conducted a posteriori. For all these analyses, the software Statistica, version 7.0 (StatSoft, Tulsa, USA) was used.

Table 2. Calibration curves for colony-forming units for H. sulfidaeris LAMA 838 and M. excellens LAMA 842 , and the curve of p. nitrophenol for the lipolytic activity.

\begin{tabular}{lccc}
\hline \multicolumn{1}{c}{ Curve } & Angular Coefficent & Intercept & $\mathbf{R}^{\mathbf{2}}$ \\
\hline Cellular concentration for LAMA 838 & 0.000000007 & -0.0445 & 0.9914 \\
Cellular concentration for LAMA 842 & 0.00008 & -0.0054 & 0.9993 \\
$\boldsymbol{p}$-nitrophenol & 9.721 & 0.0031 & 0.9994 \\
\hline
\end{tabular}




\section{RESULTS}

\section{SCREENING AND TAXONOMIC DISTRIBUTION OF LIPOLYTIC BACTERIA}

The collection of bacteria studied was obtained from sediment samples collected in deep zones of the South Atlantic Ocean by Silva et al. (2013). This collection of strains included the phyla Proteobacteria $(n=38)$, Firmicutes $(n=25)$, Actinobacteria $(n=4)$, and three unidentified strains. All strains in this collection $(n=70)$ were screened for lipolytic activity of Marine Agar plates supplemented with each of the four lipid substrates. Bacteria of the phylum Proteobacteria were not only more abundant among our strains but also showed the best lipolytic activity on the four substrates used. The substrate T80 was the least hydrolyzed, while T20 was the most commonly utilized by our strains, as shown in Figure 1.

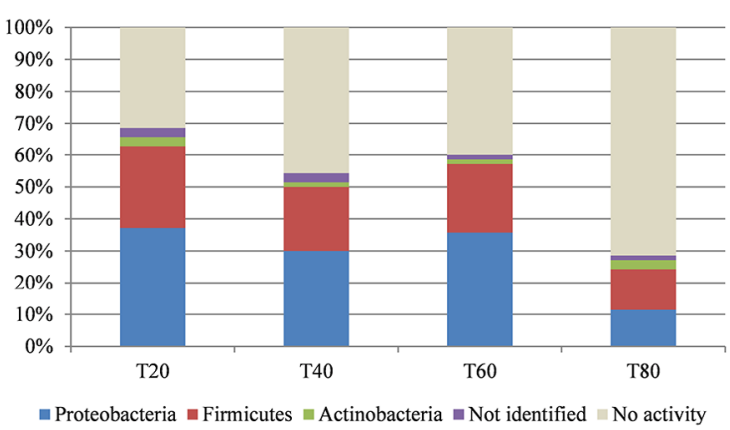

Figure 1. Frequency (\%) of lipolytic bacteria in the different bacterial phylas identified in the strains studied. The results are shown for each of the four substrates employed in the screening experiments. T20, Tween 20; T40, Tween 40; T60, Tween 60; T80, Tween 80.

Within the phyla isolated, thirteen distinct genera were identified among the lipolytic strains. The most frequent were Halomonas $(n=17)$, Bacillus $(n=9)$, Psychrobacter $(n=6)$, and Staphylococcus $(n=6)$. The lipolytic strains also represented twenty different species with predominance for Halomonas sulfidaeris $(n=5)$, Halomonas boliviensis $(\mathrm{n}=4)$, Psychrobacter nivimaris $(n=4)$, Staphylococcus cohnii subsp. urealyticus $(n=3)$.

Through this screening for lipolytic activity (Figure 2), we were able to calculate enzymatic indexes (Els) for each of the strains and substrates (Table 3). Fifity-two of the seventy strains evaluated showed lipolytic activity on at least one of the substrates. Among the five strains of $\mathrm{H}$. sulfidaeris, two hydrolyzed all lipids tested; one showed hydrolysis on T20 and T60, and two were unable to hydrolyze any of the substrates evaluated. Based on these data, we were also able to select two strains, Halomonas sulfidaeris LAMA 838 and Marinobacter excellens LAMA 842, for further studies. This selection was based on the fact that both strains (1) were able to hydrolyze the four lipid substrates, (2) had high Els, (3) represent common bacteria cultivated from deep-sea samples (Kumar et al., 2012; Ng et al., 2014; GutiérrezArnillas et al., 2016), and (4) have not been previously reported to be lipolytic species in the scientific literature. Figure 3 shows the Els of the selected bacteria. It may be noted that $H$. sulfidaeris LAMA 838 displayed higher lipolytic activity than M. excellens LAMA 842 for all lipid substrates. The highest activity was observed on T20 and both bacteria displayed significantly different Els for this substrate.

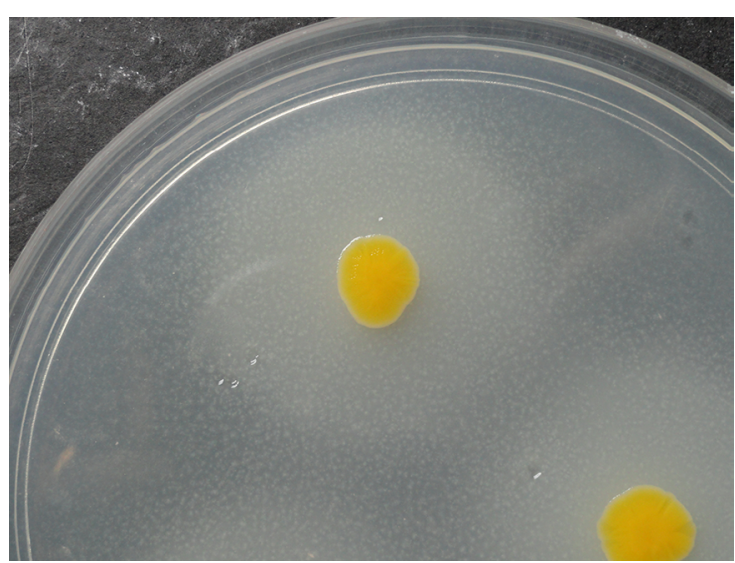

Figure 2. Marine agar plate illustrating the procedure used for screening of the lipolytic bacteria. The halo around the colony is indicative of the hydrolysis of the substrate, Tween 60 in this case.

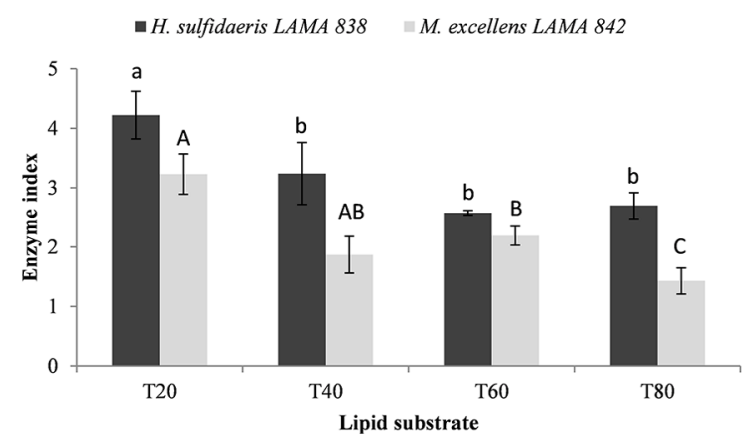

Figure 3. Enzyme indexes for the bacteria $H$. sulfidaeris LAMA 838 and M. excellens LAMA 842 for substrates Tween 20 (T20), Tween 40 (T40), Tween 60 (T60) and Tween 80 (T80) and their respective standard deviations. The letters above the bars indicate the results of the statistical analysis, small letters for $H$. sulfidaeris LAMA 838 and capital letters for M. excellens LAMA 842. Means followed by the same letter do not differ by the Tukey's test at 5\% probability. The analysis was carried out in the software Statistica version 7.0. 
Table 3. Average enzyme indexes for the bacterial strains studied and standard deviations for the four lipid substrates tested. Only the strains that were active on at least one lipid substrate are showed. T20, tween 20, T40, tween 40, T60, tween 60, and T80, tween 80.

\begin{tabular}{cccccccccc}
\hline Strain & T20 & T40 & T60 & T80 & Strain & T20 & T40 & T60 & T80 \\
\hline 616 & $2.82 \pm 0.28$ & $1.69 \pm 0.14$ & $2.24 \pm 0.11$ & $1.36 \pm 0.25$ & 720 & $2.05 \pm 0.23$ & $1.38 \pm 0.03$ & $1.34 \pm 0.03$ & $1.40 \pm 0.07$ \\
617 & $3.86 \pm 0.74$ & $3.29 \pm 0.20$ & $2.49 \pm 0.10$ & - & 723 & $1.48 \pm 0.22$ & $1.68 \pm 0.26$ & $2.15 \pm 0.17$ & - \\
622 & $2.17 \pm 0.10$ & $1.14 \pm 0.04$ & $1.57 \pm 0.07$ & - & 732 & $1.17 \pm 0.16$ & - & - & $1.23 \pm 0.03$ \\
624 & $1.52 \pm 0.13$ & $1.52 \pm 0.05$ & $2.08 \pm 0.14$ & - & 762 & $1.84 \pm 0.09$ & - & - & - \\
625 & $2.29 \pm 0.34$ & - & $1.42 \pm 0.15$ & - & 767 & $3.34 \pm 0.61$ & $1.57 \pm 0.03$ & $1.33 \pm 0.09$ & - \\
632 & $2.14 \pm 0.13$ & $1.43 \pm 0.06$ & - & $2.00 \pm 0.00$ & 780 & - & - & $1.91 \pm 0.08$ & - \\
633 & - & $1.64 \pm 0.08$ & $1.90 \pm 0.11$ & - & 781 & $2.64 \pm 0.66$ & $1.27 \pm 0.06$ & $1.37 \pm 0.10$ & - \\
634 & $3.19 \pm 0.15$ & $1.32 \pm 0.10$ & $2.08 \pm 0.12$ & - & 784 & $3.71 \pm 0.25$ & $2.57 \pm 0.13$ & $2.54 \pm 0.41$ & $1.76 \pm 0.17$ \\
636 & $2.55 \pm 0.15$ & - & $1.87 \pm 0.13$ & - & 786 & $2.86 \pm 0.32$ & $1.48 \pm 0.06$ & $4.14 \pm 0.25$ & - \\
638 & $2.06 \pm 0.06$ & $1.23 \pm 0.07$ & $1.94 \pm 0.17$ & - & 791 & $4.30 \pm 0.69$ & $2.97 \pm 0.72$ & $3.43 \pm 0.56$ & $2.33 \pm 0.17$ \\
639 & $2.26 \pm 0.20$ & $1.54 \pm 0.14$ & $2.25 \pm 0.18$ & - & 794 & $3.51 \pm 0.31$ & $2.41 \pm 0.42$ & $1.81 \pm 0.14$ & - \\
641 & $2.13 \pm 0.15$ & $1.82 \pm 0.16$ & $1.55 \pm 0.09$ & - & 796 & $1.28 \pm 0.07$ & $1.35 \pm 0.05$ & - & - \\
642 & $1.42 \pm 0.19$ & - & $1.15 \pm 0.08$ & - & 799 & $2.27 \pm 0.15$ & $1.29 \pm 0.04$ & $1.78 \pm 0.11$ & - \\
645 & $1.23 \pm 0.10$ & - & - & - & 802 & - & - & $1.77 \pm 0.36$ & - \\
670 & $2.43 \pm 0.45$ & $2.17 \pm 0.40$ & $1.31 \pm 0.11$ & $1.71 \pm 0.24$ & 810 & - & - & $2.36 \pm 0.55$ & - \\
682 & $1.34 \pm 0.01$ & $1.30 \pm 0.03$ & - & - & 817 & $3.46 \pm 0.21$ & $3.45 \pm 0.11$ & $2.92 \pm 0.14$ & $1.82 \pm 0.07$ \\
683 & $3.73 \pm 0.10$ & $2.83 \pm 0.19$ & $2.69 \pm 0.18$ & $2.16 \pm 0.07$ & 818 & $4.59 \pm 0.13$ & $1.76 \pm 0.12$ & $3.51 \pm 0.27$ & - \\
690 & $3.50 \pm 0.44$ & $2.01 \pm 0.45$ & $1.26 \pm 0.10$ & $1.26 \pm 0.10$ & 820 & $4.32 \pm 0.14$ & $3.13 \pm 0.34$ & $2.93 \pm 0.17$ & - \\
691 & $4.06 \pm 0.15$ & $3.01 \pm 0.30$ & $2.50 \pm 0.32$ & $2.23 \pm 0.85$ & 822 & $4.27 \pm 0.30$ & $2.65 \pm 0.19$ & $2.85 \pm 0.13$ & - \\
692 & $1.44 \pm 0.14$ & - & - & - & 833 & $3.39 \pm 0.29$ & $3.23 \pm 0.43$ & $2.98 \pm 0.39$ & $1.85 \pm 0.01$ \\
694 & $1.86 \pm 0.12$ & - & - & - & 837 & $1.88 \pm 0.34$ & - & - & $1.57 \pm 0.15$ \\
695 & $2.59 \pm 0.28$ & $1.33 \pm 0.11$ & $1.35 \pm 0.11$ & - & 838 & $4.22 \pm 0.40$ & $3.24 \pm 0.52$ & $2.58 \pm 0.04$ & $2.70 \pm 0.22$ \\
701 & $2.08 \pm 0.01$ & $1.54 \pm 0.26$ & - & $1.36 \pm 0.06$ & 842 & $3.23 \pm 0.34$ & $1.87 \pm 0.31$ & $2.19 \pm 0.16$ & $1.43 \pm 0.22$ \\
702 & $3.83 \pm 0.19$ & - & $1.45 \pm 0.02$ & $1.47 \pm 0.10$ & 878 & $2.86 \pm 0.83$ & $1.59 \pm 0.11$ & $1.21 \pm 0.25$ & - \\
706 & $1.73 \pm 0.14$ & $1.52 \pm 0.06$ & $1.35 \pm 0.05$ & $1.80 \pm 0.14$ & 879 & - & - & $1.42 \pm 0.09$ & - \\
713 & $2.04 \pm 0.57$ & $1.27 \pm 0.11$ & $1.36 \pm 0.10$ & $1.61 \pm 0.12$ & 892 & $3.04 \pm 0.52$ & $1.30 \pm 0.12$ & 0.06 & $1.09 \pm 0.07$ \\
\hline & & & & & & & & &
\end{tabular}

In the genome of M. excellens LAMA 842 (available from the National Center for Biotechnology Information (NCBI) database, Accession number ASM157444v1) five genes with lipase and phospholipase functions were identified (Table 4). The genomic information of $H$. sulfidaeris LAMA 838 is not available.

\section{INFLUENCE OF TEMPERATURE ON GROWTH AND LIPASE ACTIVITY}

Following the screening experiments, the influence of temperature on growth and lipase activity was evaluated in the selected strains. H. sulfidaeris LAMA 838 grew at all tested temperatures, with maximum growth rates at $30^{\circ} \mathrm{C}$ (the highest temperature tested). But to confirm that this temperature is the maximum growth temperature of this organism, higher values should be tested in the future. By contrast, M. excellens LAMA 842 did not grow at 5 or $10^{\circ} \mathrm{C}$ and showed a maximum growth rate between 20 and $25^{\circ} \mathrm{C}$ (Figure 4).

In the lipolytic activity assays, $50^{\circ} \mathrm{C}$ was identified as the highest activity temperature for LAMA 838, and between 45 and $50^{\circ} \mathrm{C}$ was highest for LAMA 842 . Again, to confirm that $50^{\circ} \mathrm{C}$ is the maximum activity temperature of LAMA 838, higher values should be tested in the future. Different from that observed for the LAMA 838 lipase, the LAMA 842 enzyme was active at all temperatures, including low temperatures, with more 


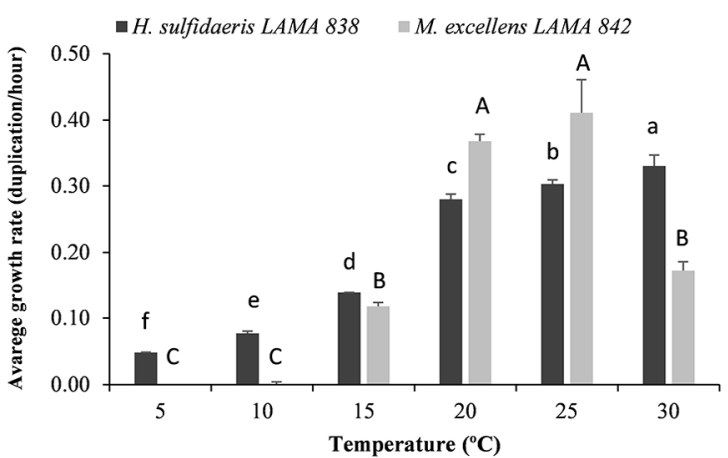

Figure 4. The influence of temperature on the growth rate of $H$. sulfidaeris LAMA 838 and M. excellens LAMA 842. The vertical bars represent the standard deviation. The letters above the bars indicate the results of the statistical analysis, small letters for $H$. sulfidaeris LAMA 838 and capital letters for M. excellens LAMA 842. Means followed by the same letter do not differ by the Tukey's test at $5 \%$ probability. The analysis was carried out in the software Statistica version 7.0 .

than $50 \%$ of the activity maintained at $3^{\circ} \mathrm{C}$, as show in Figure 5. This behavior may indicate the production of isoenzymes whose properties and regulation can be adjusted according to metabolic necessity and culture medium.

\section{INFLUENCE OF CULTURE MEDIA ON GROWTH AND LIPASE ACTIVITY}

In the last round of experiments, the influence of culture media on growth and lipase activity was evaluated. H. sulfidaeris LAMA 838 grew best in marine broth, while M. excellens LAMA 842 had a higher growth rate in marine broth supplemented with Tween 40. Both organisms had the lowest growth rate in minimal medium supplemented with Tween 40 (Figure 6). In general, $H$. sulfidaeris LAMA 838 had higher enzymatic activity then M. excellens LAMA 842 in all three culture media evaluated (Figure 6). When comparing the different media, the highest enzymatic activity was observed in marine broth supplemented with Tween 40 for both of the selected strains. Additionally, the lowest enzymatic activity was observed in unsupplemented marine broth for both organisms.

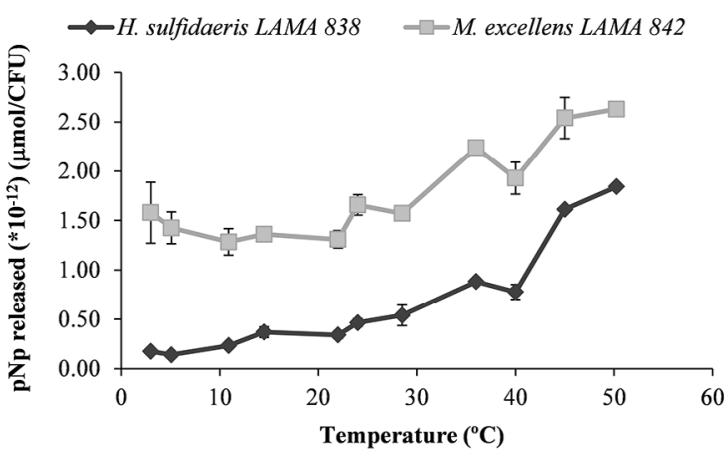

Figure 5. Residual activity of the lipases produced by $\mathrm{H}$. sulfidaeris LAMA 838 and M. excellens LAMA 842. The vertical bars represent the standard deviation.
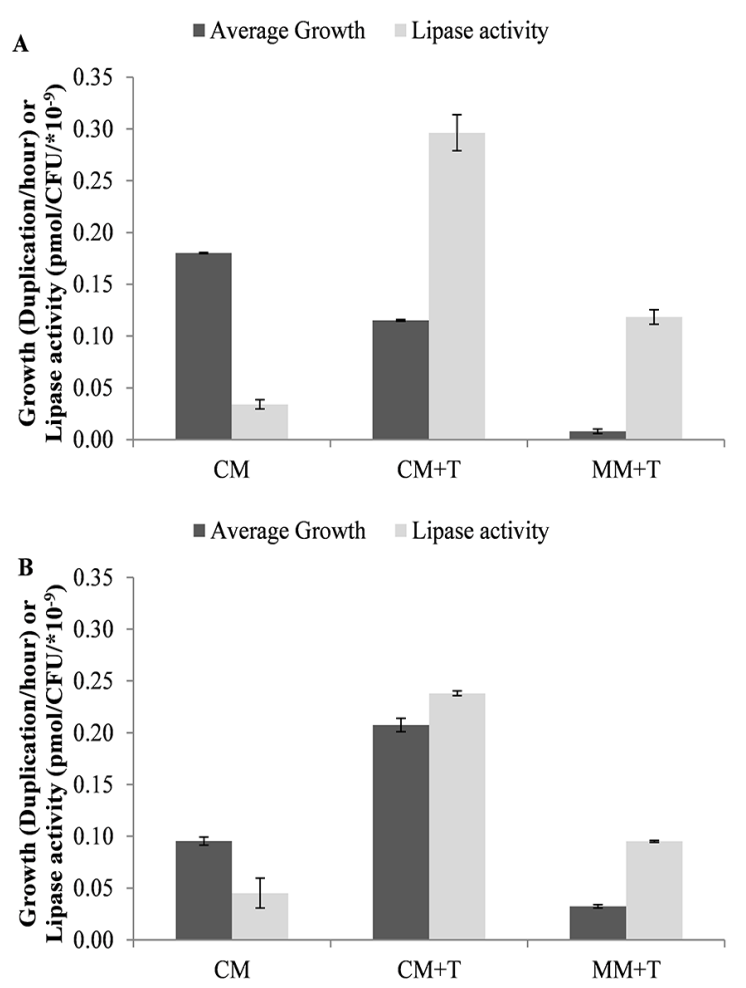

Figure 6. Growth rate (dark gray) and lipolytic activity (light gray) of $H$. sulfidaeris LAMA 838 (A) and M. excellens LAMA 842 (B) grown in Marine Broth (M.B), Marine Broth supplemented with Tween 40 (M.B+ T40) and Minimal Medium supplemented with Tween 40 $(\mathrm{MM}+\mathrm{T} 40)$. The vertical bars represent the standard deviation of the triplicates.

Table 4. Genes related to lipase and phospholipase functions identified in the genome of M. excellens LAMA 842, their product and length.

\begin{tabular}{ccc}
\hline Locus tag & Protein name & Length \\
\hline J122_RS03215 & Triacylglycerol lipase & 309 \\
J122_RS07275 & Phospholipase D family protein & 511 \\
J122_RS09230 & Patatin-like phospholipase family protein & 360 \\
J122_RS16985 & Phospholipase & 481 \\
J122_RS17820 & Phospholipase A & 372 \\
\hline
\end{tabular}




\section{DISCUSSION}

The predominant class of organisms in the samples studied was Gammaproteobacteria, which has already been reported in the scientific literature as abundant in deep-water and hydrothermal vents (Zhang et al., 2016). Marinobacter and Halomonas are also frequently found in these environments (Sun et al., 2015; Yuan et al., 2015). Nevertheless, few studies have identified $H$. sulfidaeris and M. excellens as lipase producers from deep marine waters (Silva et al., 2013). This fact propelled the search for more information on these two bacterial species, especially after the identification of substrates hydrolyzed by these microorganisms and their respective enzymatic indexes.

During the screening with lipolytic substrates, T20 and T40 were found to be the most hydrolyzed by the bacterial strains studied. Similar results were reported by Lo Giudice et al. (2006) in marine bacteria isolated from Antarctica and by Zhang et al. (2016) in microorganisms from the South Pacific Ocean. On the other hand, the substrate T80 was the least utilized by the microorganisms. This can be explained by the presence of one double bond in the molecule, which demands that the enzyme epoxide hydrolase be present to hydrolyze and break this bond for the utilization of this molecule (Woo et al., 2007). The presence of this enzyme was identified previously in the genus Marinobacter (Neilson and Allard, 2008) and may justify the results we obtained for $M$. excellens LAMA 842. In the description of the species $H$. sulfidaeris, Kaye and Baross (2004) reported its inability to hydrolyze T80. In the present study, five strains of $H$. sulfidaeris were evaluated and only two strains, LAMA 838 and LAMA 786, were capable of hydrolyzing all lipid substrates tested, including T80. Different characteristics among a group of strains of the same species are not uncommon and may be related to the origins of the different strains. For instance, LAMA 838 was the only strain of $H$. sulfidaeris among the five analyzed that originated from sediments of the Walvis Ridge Sector in the Superstation $0\left(25^{\circ} 41^{\prime} 70^{\prime \prime} \mathrm{S}, 02^{\circ} 20^{\prime} 72^{\prime \prime} \mathrm{W}\right.$ ) (Silva et al., 2013). According to Philippot et al. (2010), the adaptation to different ecological niches may influence the differentiation of bacterial strains, with the acting selective pressures resulting in strains with different genomes. From the sequence distribution pattern of the 16S rRNA gene, three subpopulations of Halomonas were identified by Kaye et al. (2011), with one ecotype predominant in deep cold waters, another in hydrothermal sources and another in the subseafloor population.
Growth was also evaluated in different culture media, and the results indicated that the growth rate of the microorganisms studied was highest in nutrient rich media without T40 (MB) (Barton, 2005), which differed from the enzymatic activity of these microorganisms, for which the best indexes were obtained in media supplemented with Tween (MB+T40 and MM+T40), nutrient-rich or minimal. These results demonstrate that lipolytic activity is not necessarily linked to complex and expensive nutrients, an observation which may make these microbial enzymes competitive in the industrial market. Polyoxyethylene sorbitol fatty acid ester has been studied as a facilitator of enzymatic reactions and their substrates, which favors the enzymatic secretion of hydrolases to the extracellular medium (Pozdnyakova et al., 2004) and maximizes biomass and lipase productivity (Byreddy et al., 2017). In the study by Nemec and Jernet (2002), a $70 \%$ increase in the secretion of Aspergilus niger hydrolases was observed in the presence of $0.1 \%$ Tween 80 ; in the present study, we observed an increase of $87 \%$ for $\mathrm{H}$. sulfidaeris and $81 \%$ for $M$. excellens in the presence of T40. When analyzing the genome of $M$. excellens LAMA 842 five genes with lipase and phospholipase functions were identified (Table 4). The presence of these genes may explain why the best growth rates were obtained in Tween medium. Their presence may also explain the activity of the LAMA 842 lipase at low temperatures, because this bacterium is not known to grow at low temperatures. These genes may also explain the potential presence of isoenzymes.

The presence of the Tween molecule in the media serves as an additional carbon source, which can be utilized by the bacteria for cell growth and the generation of biomass. It may also favor the secretion of extracellular lipases into the medium and may stimulate this activity. This influence is more evident for the bacterium $M$. excellens. By contrast, for $\mathrm{H}$. sulfidaeris the addition of Tween to the medium caused a decrease in the growth rate, while at the same time inducing better lipase activity.

In studying the physiology of bacteria belonging to the genus Halomonas, Kaye and Baross (2004) reported that the ideal conditions of growth for these organisms are not those typical of deep-sea environments: Halomonas may prefer to live in warmer environments, with temperatures approximately $30^{\circ} \mathrm{C}$. In agreement with this, $H$. sulfidaeris LAMA 838 reached its maximum growth rate at $30^{\circ} \mathrm{C}$, the highest temperature tested in the present work, and a similar result to that obtained by 
Kaye and Baross (2004), which characterized this species as mesophile. M. excellens LAMA 842, on the other hand, grew better between 20 and $25^{\circ} \mathrm{C}$, as observed previously in the type strain isolated from marine sediments in Japan (Gorshkova et al., 2003).

The results obtained in this work agree with those described previously in the literature, in which the optimum temperature for activity of extracellular enzymes such as lipases may differ from the optimal temperature for growth of the producing microorganism. This may happen because of the necessity of enzymatic activation (Feller et al., 1990). According to Bhavani et al. (2012) and Byreddy et al. (2017), the temperature, $\mathrm{pH}$, carbon source and incubation period of the microorganisms are important factors that can influence both the production of lipases and the lipolytic activity. In this context, assays conducted by Kiran et al. (2008) have shown that lipases produced by marine Pseudomonas have maximum activity between 27 and $50^{\circ} \mathrm{C}$. This is similar to our results obtained for lipases produced by $H$. sulfidaeris LAMA 838 and M. excellens LAMA 842 , which had maximum activities at $50^{\circ} \mathrm{C}$ and between 40 and $50^{\circ} \mathrm{C}$, respectively. The low temperature lipolytic activity of the LAMA 842 strain represents a prominent characteristic that is biotechnologically appreciated, since in the literature no lipase has been previously described with $50 \%$ activity at $3^{\circ} \mathrm{C}$ for the genus Marinobacter.

From a biotechnology point of view, the bacteria studied here and their lipolytic enzymes possess characteristics that are relevant to industry. H. sulfidaeris LAMA 838 was able to grow over a large temperature range, produced lipolytic enzymes that are active at high temperatures and was able to hydrolyze multiple lipid substrates. Major parts of the industrial processes that involve the use of lipases occur at temperatures above $45^{\circ} \mathrm{C}$. These higher temperatures may reduce the risks of contamination by other mesophilic microorganisms, generate higher reaction rates, and increase diffusion and solubility of the substrate (López-López et al., 2014). In the case of M. excellens LAMA 842 the activity of lipases at low temperatures stands out because this characteristic may allow for high conversion rates of substrate to product at low energy costs. These cold-active lipases also have potential uses as detergent additives in cold washes in the food industry, in the transesterification for biofuels production, and in soil or aquatic bioremediation at low temperatures (Kavitha, 2016).

\section{CONCLUSION}

It was concluded that the evaluated strain of $H$. sulfidaeris, LAMA 838, displayed a higher growth rate at $30^{\circ} \mathrm{C}$, although it grew at low temperatures as well, and its extracellular lipases were active at temperatures above $40^{\circ} \mathrm{C}$. Growth of the bacterium M. excellens LAMA 842 occurred at temperatures above $15^{\circ} \mathrm{C}$ and its lipases were active at various temperatures including low temperatures. In the evaluation of culture media, we observed a greater influence of the presence of Tween on the growth of $M$. excellens LAMA 842 in the marine broth; however, the lipolytic activity of both bacteria was stimulated with the addition of this lipid substrate in the culture medium. Thus, the composition of the medium and the cost of production vary according to the microorganism and interest. The strains studied have the potential to be used as sources of lipases for biotechnological uses such as effluent treatment and detergent supplementation. M. excellens LAMA 842 stand out among the two strains, since it showed lipolytic activity at lower temperatures and it stimulation by the lipid substrates used. In further studies the lipases of these bacteria should be purified and characterize in more detail.

\section{ACKNOWLEDGMENTS}

The funding agency Coordenação de Aperfeiçoamento de Pessoal de Nível Superior (Brazil, Process 88887.146746/2017-00) and Conselho Nacional de Desenvolvimento Científico e Tecnológico (CNPq) INCT-Mar COI (Instituto Nacional de Ciência e Tecnologia, Centro de Oceanografia Integrada, Brazil, Process 565062/2010-7) supported this work. The authors thank CNPq - INCT-Mar COI for DTI-B scholarship support provided to G. S. D. (381222/2017-9) and CNPq for scholarship provided to A. O. S. L. (Process 312363/2018-4).

\section{AUTHOR CONTRIBUTIONS}

G.S.D.: Investigation; Formal analysis; Writing - original draft.

M.C.S.: Investigation; Writing - original draft.

C.S.S.: Investigation; Writing - original draft.

L.Z.B.: Investigation; Writing - original draft.

T.M.M.: Investigation.

C.A.S.: Investigation.

A.O.S.L.: Funding acquisition; Conceptualization. 
M.A.C.S.: Funding acquisition; Conceptualization; Formal analysis; Writing - original draft; Writing - review \& editing.

\section{REFERENCES}

BARTON, L. L. 2005. Structural and functional relationships in prokaryotes, New York, Springer.

BHAVANI, M., CHOWDARY, G. V., DAVID, M. \& SCREENING, A. G. 2012. Isolation and biochemical characterization of novel lipase producing bacteria from soil samples. International Journal of Biological Engineering, 2, 18-22.

BREZNAK, J. A. \& COSTILOW, R. N. 1994. Physicochemical factors in growth. In: GERHARDT, P., MURRAY, R. G. E., WOOD, W. A. \& KRIEG, N. R. (eds.) Methods for general and molecular bacteriology. ASM Press: Washington. 137-154.

BYREDDY, A. R., RAO, N. M., BARROW, C. J. \& PURI, M. 2017. Tween 80 influences the production of intracellular lipase by Schizochytrium S31 in a stirred tank reactor. Process Biochemistry, 53, 30-35.

CHEN, R., GOU, L. \& DANG, H. 2011. Gene cloning, expression and characterization of a cold-adapted lipase from a psychrophilic deep-sea bacterium Psychrobacter sp. C18. World Journal of Microbiology and Biotechnology, 27, 431-441.

DALMASO, G. Z. L., FERREIRA, D. \& VERMELHO, A. B. 2015. Marine extremophiles: a source of hydrolases for biotechnological applications. Marine Drugs, 13, 1925-1965.

FELLER, G., THIRY, M., ARPIGNY, J. L., MERGEAY, M. \& GERDAY, C. 1990. Lipases from psychrotrophic antarctic bacteria. FEMS Mmroblology Letters, 66, 239-244.

GORSHKOVA, N. M., IVANOVA, E. P., SERGEEV, A. F., ZHUKOVA, N. V., ALEXEEVA, Y., WRIGHT, J. P., NICOLAU, D. V., MIKHAILOV, V. V. \& CHRISTEN, R. 2003. Marinobacter excellens sp. nov., isolated from sediments of the sea of Japan. International Journal of Systematic and Evolutionary Microbiology, 53, 2073-2078.

GUTIÉRREZ-ARNILLAS, E., RODRÍGUEZ, A., SANROMÁN, M. A. \& DEIVE, F. J. 2016. New sources of halophilic lipases: Isolation of bacteria from Spanish and Turkish saltworks. Biochemical Engineering Journal, 109, 170-177.

HANKIN, L. \& AGNOSTAKIS, S. L. 1975. The use of solid media for detection of enzyme production by fungi. Mycologia, 67, 597-607.

HU, Y., LIU, Y., LI, J., FENG, Y., LU, N., ZHU, B. \& XUE, S. 2015. Structural and functional analysis of low temperature active alcaline esterase from South China sediment microbial metagenomics library. Journal of Industrial Microbiology \& Biotechnology, 42, 1449-1461.

KAI, W. \& PEISHENG, Y. 2016. Optimization of lipase production from a novel strain Thalassospira permensis M35-15 using response surface methodology. Bioengineered, 7, 298-303.

KAVITHA, M. 2016. Cold active lipases-an update. Frontiers in Life Science, 9, 226-238.

KAYE, J. Z. \& BAROSS, J. A. 2004. Synchronous effects of temperature, hydrostatic pressure, and salinity on growth, phospholipid profiles, and protein patterns of four Halomonas species isolated from deep-sea hydrothermalvent and sea surface environments. Applied and Environmental Microbiology, 70, 6220-6229.

KAYE, J. Z., MÁRQUÉZ, M. C., VENTOSA, A \& BAROSS, J. A. 2004. Halomonas neptunia sp.nov., Halomonas sulfidaeris sp. nov.,
Halomonas axialensis sp. nov. and Halomonas hydrothermalis sp. nov.: halophilic bacteria isolated from deep-sea hydrothermal-vent environments. International Journal of Systematic and Evolutionary Microbiology, 54, 499-511.

KAYE, J. Z., SYLVAN, J. B., EDWARDS, K. J. \& BAROSS, A. J. 2011. Halomonas and Marinobacter ecotypes from hydrothermal vent, subseafloor and deep-sea environments. FEMS Microbiology Ecology, 75, 123-133.

KIRAN, G. S., LIPTON, A. N., KENNEDY, J., DOBSON, A. D. W. \& SELVIN, J. A. 2014. A halotolerant thermostable lipase from the marine bacterium Oceanobacillus sp. PUMB02 with an ability to disrupt bacterial biofilms. Bioengineered, 5, 3005-3018.

KIRAN, G. S., SHANMUGHAPRIYA, S., JAYALAKSHMI, J., SELVIN, J., GANDHIMATHI, R., SIVARAMAKRISHNAN, S. \& NATARAJASEENIVASAN, K. 2008. Optimization of extracellular psychrophilic alkaline lipase produced by marine Pseudomonas sp. (MSI057). Bioprocess and Biosystems Engineering, 31, 483-492.

KUMAR, S., KARAN, R., KAPOOR, S., SINGH, S. P. \& KHARE, S. K. 2012. Screening and isolation of halophilic bacteria producing industrially important enzymes. Brazilian Journal of Microbiology, 43, 1595-1603.

LAILAJA, V. P. \& CHANDRASEKARAN, M. 2013. Detergent compatible alkaline lipase produced by marine Bacillus smithii BTMS 11. World Journal of Microbiology and Biotechnology, 29, 1349-1360.

LO GIUDICE, A., MICHAUD, L., DE PASCALE, D., DE DOMENICO, M., DI PRISCO, G., FANI, R. \& BRUNI, V. 2006. Lipolytic activity of Antarctic cold-adapted marine bacteria (Terra Nova Bay, Ross Sea). Journal of Applied Microbiology, 101, 1039-1048.

LÓPEZ-LÓPEZ, O., CERDÁN, M. E. \& GONZÁLEZ SISO, M. I. 2014. New extremophilic lipases and esterases from metagenomics. Current Protein and Peptide Science, 15, 445-455.

MUSA, H., HAFIZ KASIM, F., NAGOOR GUNNY, A. A., GOPINATH, S. C. B. \& AZMIER AHMAD, M. 2019. Enhanced halophilic lipase secretion by Marinobacter litoralis SW-45 and its potential fatty acid esters release. Journal of Basic Microbiology, 59, 87-100.

NEILSON, A. H. \& ALLARD, A. S. 2008. Environmental degradation and transformation of organic chemicals, Boca Raton, CRC Press.

NEMEC, T. \& JERNEJC, K. 2002. Influence of tween 80 on lipid metabolism of an Aspergillus niger strain. Applied Biochemistry and Biotechnology, 3, 229-238.

NG, H. J., LÓPEZ-PÉREZ, M., WEBB, H. K., GOMEZ, D., SAWABE, T., RYAN, J., VYSSOTSKI, M., BIZET, C., MALHERBE, F., MIKHAILOV, V. V., CRAWFORD, R. J. \& IVANOVA, E. P. 2014. Marinobacter salarius sp. nov. and Marinobacter similis sp. nov., isolated from Sea Water. PLoS One, 9, e106514. DOI: https://doi:10.1371/journal.pone.0106514

ODISI, E. J., SILVESTRIN, M. B., TAKAHASHI, R. Y. U., SILVA, M. A. C. \& LIMA, A. O. S. 2012. Bioprospection of cellulolytic and lipolytic south Atlantic deep-sea bacteria. Electronic Journal of Biotechnology, 15. DOI: https://doi:10.2225/vol15-issue 5- fulltext-17

OVES, M., QARI, H. A., FELEMBAN, N. M., KHAN, M. Z., REHAN, Z. A. \& ISMAIL, I. M. I. 2017. Marinobacter lipolyticus from Red Sea for lipase production and modulation of silver nanomaterials for anti-candidal activities. IET Nanobiotechnol, 11, 403-410. 
PEREZ, J. A. A., ALVES, E. S., CLARK, M. R., BERGSTAD, O. A., GEBRUK, A., CARDOSO, I. A. \& ROGACHEVA, A. 2012. Patterns of life on the southern Mid-Atlantic Ridge: Compiling what is known and addressing future research. Oceanography, 4, 16-31.

PHILIPPOT, L., ANDERSSON, S. G., BATTIN, T. J., PROSSER, J. I., SCHIMEL, J. P., WHITMAN, W. B. \& HALLIN, S. 2010. The ecological coherence of high bacterial taxonomic ranks. Nature Reviews Microbiology, 8, 523-529.

PINSIRODOM, P. \& PARKIN, K. L. 2001. Lipase assays. Current Protocols in Food Analytical Chemistry, C3.1.1-C3.1.13. DOI: https://doi.org/10.1002/0471142913.fac0301s00

POZDNYAKOVA, N. N., RODAKIEWICZ-NOWAK, J. \& TURKOVSKAYA, O. V. 2004. Catalytic properties of yellow laccase from Pleurotus ostreatus D1. Journal of Molecular Catalysis B: Enzymatic, 30, 19-24.

SILVA, M. A. C., CAVALETT, A., SPINNER, A., ROSA, D. C., JASPER, R. B., QUECINE, M. C., BONATELLI, M. L., KLEINER, A. P., CORÇÃO, G. \& LIMA, A. S. O. 2013. Phylogenetic identification of marine bacteria isolated form deep-sea of the eastern South Atlantic Ocean. SpringerPlus, 2, 127. DOI: https:// doi:10.1186/2193-1801-2-127

SMIBERT, R. M. \& KRIEG, N. R. 1994. Phenotypic characterization. In: GERHARDT, P., MURRAY, R. G. E., WOOD, W. A. \& KRIEG, N. R. (eds.) Methods for General and Molecular Bacteriology. Washington: American Society for Microbiology. 607-654.
SUN, Q. L., WANG, M. Q. \& SUN, L. 2015. Characteristics of the cultivable bacteria from sediments associated with two deep-sea hydrothermal vents in Okinawa Trough. World Journal of Microbiology and Biotechnology, 31, 2025-2037.

TREICHEL, H., DE-OLIVEIRA, D., MAZUTTI, M. A., DI-LUCCIO, M. \& OLIVEIRA, J. V. 2010. A review on microbial lipases production. Food and Bioprocess Technology, 3, 182-196.

WHITE, D., DRUMMOND, J. \& FUQUA, C. 2012. The physiology and biochemistry of prokaryotes, Oxford, Oxford University Press.

WOO, J. H., HWANG, Y. O., KANG, S. G., LEE, H. S., CHO, J. C. \& KIM, S. J. 2007. Cloning and characterization of tree epoxide hidrolases from a marine bacterium, Erytrobacter litoralis HTCC2594. Applied Microbiology and Biotechnology, 76, 365375.

YUAN, J., LAI, Q., SUN, F., ZHENG, T. \& SHAO, Z. 2015. The diversity of $\mathrm{PAH}$-degrading bacteria in a deep-sea water column above the Southwest Indian Ridge. Frontiers in Microbiology, 6, 853.

ZHANG, L., WANG, Y., LIANG, J., SONG, Q. \& ZHANG, X. H. 2016. Degradation properties of various macromolecules of cultivable psychrophilic bacteria from the deep-sea water of the South Pacific Gyre. Extremophiles, 20, 663-671. 